УДК 349.2

DOI https://doi.org/10.32844/2618-1258.2019.6.16

ОБУШЕНКО Н.М.

\title{
ТЕХНОЛОГІЯ ТА ЕТАПИ СИСТЕМАТИЗАЦІЇ ТРУДОВОГО ЗАКОНОДАВСТВА
}

Метою статті є визначити сутність технології та охарактеризувати етапи систематизації трудового законодавства. Так, у статті на основі аналізу наукових поглядів вчених надано авторське визначення поняття технології систематизації трудового законодавства. Обгрунтовано, що особливості етапів, методів і операцій систематизації трудового законодавства зумовлюються вибраною формою іiі здійснення. Розглянуто початковий етап систематизації трудового законодавства, на якому приймається рішення про іії проведення та виділення необхідних ресурсів для її належного здійснення. У разі проведення офіційної систематизації таке рішення приймається відповідним компетентним органом держави. Особливою специфікою у цьому разі вирізняється кодифікація, яка прямо пов'язана із законотворчістю. Питання про кодифікацію трудового законодавства, тобто створення Кодексу з питань трудових і тісно пов'язаних із ними відносин, вирішується в порядку, встановленому Регламентом ВРУ. Підкреслено, що наведений у статті порядок здійснення систематизації трудового законодавства має загальний характер і може ускладнюватися та доповнюватися певними різновидами методів, засобів, операцій залежно від вибраної форми ії проведення, а також етапу, на якому перебуває цей процес. Визначено, що планування - це одна із ключових організаційних процедур систематизації досліджуваного законодавства, яка передбачає визначення: цілей та завдань систематизації трудового законодавства залежно від ії виду; ключових принципів здійснення систематизації; стадій (етапів) здійснення систематизації; строків здійснення окремих етапів та систематизації загалом; розподіл функціональних обов'язків усередині робочої групи, що здійснює систематизацію; методів і засобів проведення систематизації, а також обсягів необхідних для цього ресурсів. Зроблено висновок, що систематизація незалежно від ії різновиду являє собою досить складний процес, якість та результативність якого прямим і значним чином залежить від обраних методів, засобів, операцій та алгоритмів його здійснення, які йменуються технологією систематизації.

Ключові слова: технологія, техніка, юридична техніка, систематизація, трудове законодавства, етап систематизації.

The purpose of the article is to determine the essence of technology and to characterize the stages of systematization of labor legislation. Thus, in the article, based on the analysis of scientific views of scientists, the author defines the concept of technology of systematization of labor legislation. It is substantiated that the peculiarities of stages, methods and operations of systematization of labor legislation are conditioned by the chosen form of its implementation. The initial stage of the systematization of labor legislation, at which it is decided to implement it and allocate the necessary resources for its proper implementation. In the case of official systematization, such decision shall be taken by the appropriate competent authority of the State. In this case, a specific feature is the codification, which is directly related to lawmaking. The issue of codification of labor legislation, that is, the creation of the Code of Labor and closely related relations with them, is resolved in the manner established by the VRU Regulation. It is emphasized that the procedure for the systematization of labor legislation described in the article is of a general nature and may be complicated and supplemented by certain varieties of methods, means, operations depending on the chosen form of its conduct, as well as the stage at which this process is. It is determined that planning is one of the

(C) ОБУШЕНКО Н.М. - кандидат юридичних наук, старший науковий співробітник секретаріату Вченої ради (Дніпропетровський державний університет внутрішніх справ) 
key organizational procedures for the systematization of the studied legislation, which provides the definition of: goals and objectives of the systematization of labor legislation, depending on its type; key principles of systematization; stages of systematization; terms of implementation of separate stages and systematization as a whole; the distribution of functional responsibilities in the middle of a systematic task force; methods and means of carrying out the systematization, as well as the amount of resources required for this purpose. It is concluded that systematization, regardless of its variety, is a rather complicated process, the quality and effectiveness of which is directly and significantly dependent on the selected methods, means, operations and algorithms for its implementation, which are called systematization technology.

Key words: technology, technology, legal technique, systematization, labor legislation, stage of systematization.

Вступ. Нині законодавство України у сфері праці представлено цілою низкою нормативно-правових актів різної юридичної сили, кожен з яких спрямований врегулювати окремі специфічні правовідносини в цій галузі. Разом із тим нині говорити про те, що трудове законодавство нашої держави $є$ досконалим, у жодному випадку не можна. Воно потребує комплексного та всебічного оновлення. Одним із способів такого «оновлення» $є$ його систематизація. Важливість питання здійснення систематизації трудового законодавства в Україні зумовлює необхідність дослідження технології та етапів ії реалізації із тим, щоб визначити найбільш доцільні та ефективні підходи до ії проведення в умовах реалій іперспектив розвитку українських суспільства та держави.

Проблема систематизації трудового законодавства неодноразово була в полі зору різних науковців. Зокрема, їй приділяли увагу Л.В. Могілевський, О.В. Петришин, С.П. Погребняк, В.С. Смородинський, А.М. Ришелюк, С.В. Пєтков, Г.О. Спіцина, С.М. Прилипко, О.М. Ярошенко, В.В. Жернаков, О.І. Кисельова, Н.П. Долгіх, В.П. Марущак та багато інших. Однак, незважаючи на суттєві здобутки науковців, більшість їхніх наукових розробок було присвячено загальним питанням систематизації трудового законодавства, при цьому проблема технології та етапів систематизації трудового законодавства фактично залишилась поза увагою правників.

Постановка завдання. Саме тому мета статті - визначити сутність технології та охарактеризувати етапи систематизації трудового законодавства.

Результати дослідження. Науковцями поки що небагато уваги приділено висвітленню сутності та обгрунтуванню значення цього різновиду соціальної технології. Так, наприклад, I. Кізіма вважає, що юридична технологія є видом суспільної технології, якій притаманні риси останньої, сукупністю прийомів і засобів, що спрямовані на чітку й ефективну організацію дій для здійснення правового захисту. Іншими словами, юридична технологія - це мистецьке оперування правовою матерією, вибудовування правової позиції, запрограмованої на отримання позитивного результату. Юридична технологія - це майстерне конструювання юридичного процесу за допомогою матеріальних та процесуальних норм [1]. Юридична технологія, пише I. Шутак, це ресурсно-забезпечена складна юридична діяльність, яка охоплює систему логічно взаємопов'язаних операцій, визначається рівнем розвитку правової системи суспільства. Така юридична діяльність грунтується на знанні про оптимальну взаємодію юридичних, юридично-технічних i технологічних засобів, яке використовують для досягнення певних правових цілей і зумовлює певні юридичні наслідки [2]. К.М. Умедов пропонує розуміти юридичну технологію як сукупність науково обгрунтованих засобів, методів, парадигм, тактики, стратегії і правила застосування самих методів, способів, прийомів, тактики і стратегії, спрямованих на конкретний об'єкт (предмет (в юридичній матерії)) з метою зміни його форми i/або змісту або спрямованих на відносини по створенню нового правового матеріалу, реалізації правового матеріалу, а також з'ясування і тлумачення змісту правового матеріалу, черговість застосування правових норм, а також порядок побудови структурних елементів правової норми, в правовій системі [3].

Варто звернути увагу на те, що у правознавстві, окрім поняття «юридична технологія», $\epsilon$ поняття «юридична техніка», з приводу співвідношення яких серед дослідників немає єдиної точки зору. Так, М.П. Проніна, вивчаючи співвідношення понять «юридична техніка» $\mathrm{i}$ «юридична технологія», пише, що вони містять ті самі елементи і динаміку, якими характеризуються техніка та технологія. Подібно до того як техніка використовується на виробництві, для забезпечення технологічного процесу юридична техніка за допомогою цілого набору необхідних правил, прийомів і засобів дає змогу компетентним органам привносити у сферу правового регулювання найбільш раціональні і необхідні правові акти, що несуть різне правове і функціональне наван- 
таження. Своєю чергою, компоненти технологічних процесів за своєю природою схожі з структурними елементами юридичної технології. Останні допомагають законодавцю застосовувати необхідні прийоми, засоби та правила з арсеналу юридичної техніки для створення якісних юридичних актів, спрямованих на гармонізацію різних суспільних відносин. Розглянувши основні підходи до поняття техніки і різноманітність трактувань дефініції «технологія», дослідниця доходить висновку, що техніка - це сукупність засобів людської діяльності, створюваних для здійснення процесів виробництва, а 3 технологією пов'язують операції виробничого процесу, тобто техніка - це сукупність коштів, а технологія - сукупність операцій. При цьому засіб - це спосіб, інструмент, за допомогою якого здійснюється та чи інша діяльність, а операція - одиниця технологічного процесу, виконувана безперервно і одночасно чітко визначеним суб'єктом. Таким чином, можна говорити, що юридична техніка становить інструментальну частину технології. М.П. Проніна підкреслює, що в юриспруденції ми, в першу чергу, маємо справу 3 юридичною технологією, а не з матеріальними об'єктами, тобто технікою у вузькому їі розумінні. Оскільки термін «юридична техніка» вже є усталеним і використовується більшістю вчених, доцільно залишити його в юридичній термінології, але вкладати в його зміст, насамперед, юридичну технологію, а основні зусилля вчених спрямувати на вирішення і дослідження більш важливих проблем юридичної техніки [4].

Отже, з огляду на наукові напрацювання вищезгаданих та інших дослідників видається за доцільне визначити технологію систематизації трудового законодавства як процедуру, алгоритм реалізації прийомів, методів, способів та засобів з упорядкування та вдосконалення зазначеного законодавства. Тобто технологія - це методи і способи, інструменти і засоби систематизації в дії.

Що стосується етапів систематизації, то вони являють собою певну, порівняно самостійну, логічно завершену частину, стадію діяльності щодо систематизації трудового законодавства. Кожному етапу систематизації властиві ті чи інші методи, засоби і процедури їх здійснення.

Особливості етапів, методів і операцій систематизації трудового законодавства зумовлюються обраною формою іiї здійснення. Разом із тим можна виокремити загальні кроки і заходи в цій діяльності:

1) початковий етап, на якому приймається рішення про їі проведення та виділення необхідних ресурсів для їі належного здійснення. У разі проведення офіційної систематизації таке рішення приймається відповідним компетентним органом держави. Особливою специфікою в цьому разі вирізняється кодифікація, яка прямо пов'язана із законотворчістю. Питання про кодифікацію трудового законодавства, тобто створення Кодексу з питань трудових і тісно пов'язаних із ними відносин, вирішується у порядку, встановленому Регламентом ВРУ;

2) підготовчий етап, який передбачає:

а) по-перше, формування робочої групи для проведення роботи із систематизації трудового законодавства. Проведення систематизації законодавства взагалі та трудового зокрема, особливо здійснення його кодифікації, є надзвичайно важливим і відповідальним завданням, виконання якого вимагає від його виконавців високого рівня знань і навичок у сфері юриспруденції, лінгвістики, економіки, політології, інформаційних технологій. Тому дуже важливо, щоб у робочій групі із питань кодифікації трудового законодавства були представлені не лише науковці та політичні діячі, але й юристи-практики, представники організацій роботодавців та працівників, фахівці у сфері інформаційних та комп'ютерних технологій;

б) по-друге, планування проведення систематизації досліджуваного законодавства. Планування - розробка загальної концепції розвитку системи управління, обгрунтування конкретних задач, термінів, шляхів їх реалізації, тобто програми дій (заходів) на перспективний період [5, с. 158]. Планування, пише I.M. Петрови, - процес формування цілей, визначення пріоритетів, засобів і методів їх досягнення на основі знань про закономірності функціонування різних господарських систем і обліку можливих змін умов діяльності [6]. В.М. Нелеп, досліджуючи сутність та значення планування, зазначає, що одні з головних властивостей людського розуму - здатність до передбачення і вибору. Саме передбачення і вибір є основними етапами й метою планування спрогнозувати розвиток подій, явищ і вибрати найкращий варіант. Цим займаються всі люди й усі колективи. Людина, перш ніж розпочати будь-яку справу, має ретельно продумати, що саме, до якого терміну, якими способами, за допомогою яких засобів і з якою ефективністю вона має це зробити. У протилежному разі іiі наміри можуть бути нереалізованими. Отже, першою і основоположною стадією управління будь-яким видом доцільної діяльності завжди є процес поставлення мети і віднаходження способів її досягнення. А це, зрештою, і є функції планування. Чому ми плануємо? Тому що турбуємось про те, що має відбутись. Тому що прагнемо передбачати і ді- 
яти, випереджаючи час. Тому що завдяки плануванню можемо уникнути помилок і використати наявні можливості. I, що не менш важливо, планування дає змогу позбутися невизначеності або ж зменшити ії ступінь, впливає на поведінку працівника в організації. Планування - це цілеспрямована інтелектуальна діяльність людей, що має на меті визначення цілей і завдань функціонування певних систем (підприємство, район, держава...) та шляхів і методів досягнення цих цілей і завдань. Тобто планування передбачає прийняття заздалегідь рішення про те, що робити, коли робити, хто і як буде робити, проектування бажаного майбутнього та ефективних шляхів його досягнення. Образно кажучи, планування - це міст між нашим нинішнім становищем і тим, якого ми прагнемо [7]. Г. Мінцберг тлумачить планування як формалізовану процедуру, спрямовану на отримання чітко визначеного результату, яка має форму інтегрованої системи рішень [8, с. 11]. Г.М. Тарасюк та Л.І. Шваб розуміють планування як процес підготовки рішень про цілі, способи і методи їх досягнення шляхом цілеспрямованої порівняльної оцінки різних альтернативних варіантів дій у передбачувальних умовах, i їх прийняття завжди пов'язано з використанням ресурсів, то ресурси підприємства і $є$ більшою мірою предметом планування на підприємстві [9]. Б.В. Погріщук та О.І. Марченко в розрізі вивчення планування на підприємстві зазначають, що воно, тобто планування, являє собою процес складання різних планів на підставі сукупності взаємно узгоджених показників його соціально-економічного розвитку з визначенням номенклатури, асортименту й обсягів виробництва продукції, ринків збуту, величини ресурсів і джерел їх фінансування, витрат і доходів тощо. Воно зорієнтоване на найкраще використання всіх видів ресурсів і запобігання помилкових дій, які можуть зумовити зниження ефективності господарювання. Планування покликане за можливості заздалегідь враховувати всі зовнішні і внутрішні фактори, що забезпечують сприятливі умови для нормального функціонування підприємства. Спираючись на минулі і сучасні фактичні та нормативні показники, планування націлене на окреслення і контроль майбутнього процесу розвитку підприємства, на постійне його зміцнення шляхом зведення до мінімуму розбіжностей між імовірним і бажаним майбутнім станом за умов певних дій під впливом навколишнього середовища. Отже, як доходять висновку дослідники, сутність планування полягає в конкретизації та обгрунтуванні цілей і завдань діяльності та розвитку підприємства в плановому періоді, виборі ресурсів, способів і засобів, необхідних для їхнього досягнення та отримання бажаних кінцевих результатів [10].

Отже, планування - це одна із ключових організаційних процедур систематизації досліджуваного законодавства, яка передбачає визначення:

- цілей та завдань систематизації трудового законодавства, залежно від іï виду;

- ключових принципів здійснення систематизації;

- стадій (етапів) здійснення систематизації;

- строків здійснення окремих етапів та систематизації загалом; зацію;

- розподіл функціональних обов'язків усередині робочої групи, що здійснює систематисурсів;

- методів і засобів проведення систематизації, а також обсягів необхідних для цього ре-

3) безпосереднє проведення роботи з упорядкування і вдосконалення системи трудового законодавства. Цей етап включає такі операції:

- по-перше, визначення та збір нормативно-правового матеріалу, що підлягає систематизації. У процесі проведення таких складних форм систематизації, як консолідація та, тим більше, кодифікація, їм можуть передувати більш прості форми систематизації - облік та (або) інкорпорація, завдяки яким забезпечується розміщення зібраної інформації в найбільш доцільній і корисній для подальшої систематизації послідовності. У процесі проведення обліку чи інкорпорації 3 метою підвищення якості здійснення консолідації чи кодифікації необхідно чітко визначитися 3 критеріями, за якими перші будуть здійснюватися, зокрема це можуть бути: юридична сила нормативно-правових актів; дата їх прийняття (тобто хронологічний критерій); предмет (коло питань, які регламентує відповідний нормативно-правовий акт); суб'єкт прийняття нормативно-правового акта тощо;

- по-друге, вивчення обраних нормативно-правових актів. Зміст цього етапу залежить від того, який саме вид систематизації проводиться. Так, кодифікація, на відміну від інших форм систематизації, передбачає глибоке опрацювання вибраного для систематизації нормативно-правового матеріалу на предмет його стану, наявних у ньому недоліків;

- по-третє, безпосередньо впорядкування законодавства за вибраними критеріями. На цьому етапі залежно від обраної форми систематизації реалізуються відповідні техніко-юридичні 
прийоми і методи формування, викладення, розміщення нормативно-правового матеріалу. 3 огляду на сучасний стан законодавства з питань використання найманої праці в Україні, найбільш доцільним та перспективним видається здійснення саме кодифікації, яка пов язана 3 широким використанням юридичних, логічних, лінгвістичних та інших прийомів і правил;

4) оцінювання отриманих результатів. Оцінювання $\epsilon$ вирішальним чинником у визначенні того, чи досягла певна програма своїх цілей. Головне питання оцінювання полягає, як зазначає автор, у тому, чи політика або програма змінює становище на краще чи має вплив [11, с. 85]. Оцінювання, пишуть Ю.П. Сурмін та ін., являє собою процес порівняння діяльності та/чи результатів виконання програми або політики із цілями, завданнями, комплексом явних або неявно виражених стандартів із метою внесення необхідних адміністративних чи політичних змін. Оцінювання $\epsilon$ аналітичною діяльністю, спрямованою на збір, аналіз, тлумачення та передавання інформації про економічність, ефективність, результативність політики, програм, проектів, які здійснюються $з$ метою поліпшення соціальних умов [12, с. 504]. Тобто оцінювання систематизації трудового законодавства - це встановлення рівня відповідності отриманих внаслідок ії здійснення результатів поставленим цілям. Особливості оцінювання зумовлюються видом систематизації. Так, консолідація та кодифікація зазнають значно більшої кількості різного роду експертних перевірок (як-то юридична, логічна, лінгвістична, політична, громадська тощо);

5) завершальний етап, який передбачає затвердження компетентним суб`єктом, оформлення та видання результатів систематизації у відповідній формі: кодекс, звід, збірник тощо.

Висновки. Отже, систематизація, незалежно від іiї різновиду являє собою досить складний процес, якість та результативність якого прямим і значним чином залежить від обраних методів, засобів, операцій та алгоритмів його здійснення, які йменуються технологією систематизації. Наведений вище порядок здійснення систематизації трудового законодавства має загальний характер і може ускладнюватися та доповнюватися певними різновидами методів, засобів, операцій залежно від вибраної форми ії проведення, а також етапу, на якому знаходиться цей процес.

\section{Список використаних джерел:}

1. Кізіма І. Юридичні технології та нестандартне використання процесуальних інститутів. Київ, 2010. URL: http://ut.kiev.ua/new/index.php?option=com_content\&task=view\&id=1392\& Itemid $=39$.

2. Шутак І. Юридична техніка і технологія: теорія та практика застосування. Вісник Львівського університету. Серія юридична. 2016. Вип. 63. С. 37-45. URL: http://nbuv.gov.ua/UJRN/ Vlnu_yu_2016_63_7.

3. Умедов К.М. Юридичечская технология. Universum: экономика и юриспрудениія. 2018. № 12 (57). URL: https://cyberleninka.ru/article/n/yuridicheskaya-tehnologiya-1.

4. Пронина М.П. Соотношение понятий «юридическая техника» и «юридическая технология». Юридический мир. 2013. N 6. URL: http://center-bereg.ru/1371.html.

5. Коренев А.П. Административное право России. Часть первая. Учебник / Под редакцией д.ю.н., проф. А.П. Коренева. Москва : МЮИ МВД России. Изд-во «Щит-М», 1998. 280 с.

6. Економіка та фінанси підприємства : підручник / И.М. Петрович, Л.М. Прокопишин-Рашкевич. Львів, 2014. 408 c. URL: https://pidruchniki.com/1281041964682/ekonomika/ planuvannya_diyalnosti_pidpriyemstva.

7. Нелеп В.М. Планування на аграрному підприємстві. Київ : КНЕУ, 2004. 495 с. URL: https://buklib.net/books/21929/. 2008. $389 \mathrm{c}$.

8. Мінцберг Г. Зліт та падіння стратегічного планування. Київ : Вид-во Олексія Капусти.

9. Тарасюк Г.М., Шваб Л.І. Планування діяльності підприємства : Навчальний посібник. Київ : «Каравела», 2003. 432 c. URL: https://buklib.net/books/22258/

10. Погріщук Б.В., Марченко О.І. Планування і контроль на підприємстві. Підручник. Тернопіль : Крок, 2015. 682 c. URL: https://pidruchniki.com/92310/finansi/sutnist_neobhidnist_rol_ osoblivosti_planuvannya_suchasnih_umov

11. Пал Л. Аналіз політики [Текст] / пер. з англ. І. Дзюб. Київ : Основи, 1999. 422 с.

12. Енциклопедичний словник $з$ державного управління / уклад.: Ю.П. Сурмін, В.Д. Бакуменко, А.М. Михненко та ін.; за ред. Ю.В. Ковбасюка, В.П. Трощинського, Ю.П. Сурміна. Київ : НАДУ, 2010. $820 \mathrm{c}$. 